\title{
LAJU PERTUMBUHAN TERUMBU KARANG Acropora formosa DI PULAU MENJANGAN KECIL, TAMAN NASIONAL KARIMUNJAWA
}

\author{
Growth Rate of Coral Reef Acropora formosa In Menjangan Kecil Island, \\ Karimunjawa National Park
}

\section{Choirun Nisa Akbar Rizqika, Supriharyono*) dan Nurul Latifah}

\author{
Program Studi Manajemen Sumberdaya Perairan, Departemen Sumberdaya Akuatik \\ Fakultas Perikanan dan Ilmu Kelautan, Universitas Diponegoro \\ Jl. Prof. Soedarto, SH, Tembalang, Semarang, Jawa Tengah - 50275 \\ Email : chnisa96@gmail.com
}

\begin{abstract}
ABSTRAK
Salah satu pulau di Taman Nasional Karimunjawa yang sering dikunjungi wisatawan adalah Pulau Menjangan Kecil. Wisatawan tertarik mengunjungi Pulau Menjangan Kecil dikarenakan keanekaragaman ekosistemnya, terutama ekosistem terumbu karang dan letaknya yang dekat dengan pulau utama. Namun, aktivitas pariwisata tersebut menyebabkan terjadinya degradasi ekosistem terumbu karang. Tujuan dari penelitian ini adalah untuk mengetahui kondisi fisika kimia perairan, tutupan terumbu karang dan jenis karang yang hidup di titik pengamatan , laju pertumbuhan karang dan korelasi antara variabel fisika kimia perairan terhadap laju pertumbuhan terumbu karang. Metode penelitian menggunakan metode eksplanatif dan dianalisa menggunakan SPSS 23 dan Microsoft Excel 2013. Hasil yang diperoleh adalah kualitas perairan di lokasi tersebut mendukung pertumbuhan ekosistem terumbu karang dengan suhu yang berkisar $27-30^{\circ} \mathrm{C}$, kecerahan sampai dasar dan salinitas sebesar $35 \mathrm{ppm}$. Tutupan terumbu karang di titik pengamatan tergolong baik dengan persentase penutupan sebesar $61,92 \%$. Jenis karang yang dominan adalah jenis Acropora formosa dan Acropora divaricata. Laju pertumbuhan karang yang diukur adalah jenis Acropora formosa dengan nilai sebesar $5,47 \mathrm{~mm} /$ bulan. Berdasarkan nilai $\mathrm{R}^{2}$ pada grafik rata-rata laju pertumbuhan terumbu karang, waktu pengukuran memiliki pengaruh sebesar 95,1\% terhadap laju pertumbuhan karang. Hasil uji Pearson menunjukkan variabel fisika kimia perairan yang memiliki hubungan terhadap laju pertumbuhan terumbu karang adalah arus dan pasang surut air laut dengan nilai Sig. 0,027<0,05 dan Sig. 0,046<0,05. Temperatur air laut tidak memiliki korelasi terhadap laju pertumbuhan terumbu karang dengan nilai Sig. 0,364>0,05.
\end{abstract}

Kata Kunci : Kerusakan Karang, Laju Pertumbuhan, Acropora formosa

\begin{abstract}
One of the islands in Karimunjawa National Park that often visited by tourists is the Menjangan Kecil Island. Tourists are interested to visit Menjangan Kecil Island because the diversity, especially the coral reef ecosystem and its location that close to the main island. However, these tourism activities cause degradation of coral reef. The purpose of this study was to determine the physical chemistry of the waters, coral reef cover and the types of coral, the growth rate of coral and the correlation between the variables of physical chemistry of the waters on the growth rate of coral reefs. The research method used explanatory method and analyzed using SPSS 23 and Microsoft Excel 2013. The quality of water in these locations supported the growth of coral reef ecosystems with temperatures ranging from $27-30^{\circ} \mathrm{C}$, brightness to base and salinity of $35 \mathrm{ppm}$. Coral reef cover at the observation point is classified as good with a closing percentage of $61.92 \%$. The dominant coral species are Acropora formosa and Acropora divaricata. The measured coral growth rate was Acropora formosa with a value of $5.47 \mathrm{~mm} / \mathrm{month}$. Based on the $R^{2}$ value on the graph of the average growth rate of coral reefs, the measurement time has an influence on the growth rate of the coral. The results of Pearson's test showed that the physics of water chemistry variables that have a relationship to the growth rate of coral reefs are currents and tides with the value of Sig. $0.027<0.05$ and Sig. $0.046<0.05$. Sea water temperature does not have a correlation to the growth rate of coral reefs with the value of Sig. $0.364>0.05$.
\end{abstract}

Keywords : Coral damage, Growth Rate, Acropora formosa

*) Penulis Penanggung Jawab 


\section{PENDAHULUAN}

Taman Nasional Karimunjawa memiliki potensi yang tinggi diberbagai sektor, hal ini dikarenakan oleh keanekaragaman hayati yang tinggi. Sektor pariwisata mempunyai nilai penting dan memberi kontribusi diberbagai bidang. Pengembangan sektor pariwisata secara langsung dapat meningkatkan pendapatan masyarakat terutama masyarakat lokal di masing-masing destinasi wisata. Pariwisata yang paling banyak diminati di Taman Nasional Karimunjawa adalah pariwisata bahari. Oleh karena itu ekosistem terumbu karang merupakan ekosistem penting bagi masyarakat karimunjawa. Hal ini diperkuat oleh Salim (2012), bahwa sumberdaya alam pesisir memiliki potensi yang dapat dimanfaatkan untuk kepentingan wisata. Aktifitas wisata merupakan suatu bentuk pemanfaatan sumberdaya alam yang mengandalkan jasa alam untuk suatu kepuasan.

Salah satu spot wisata yang paling sering dikunjungi wisatawan di Taman Nasional Karimunjawa adalah Pulau Menjangan Kecil. Pulau Menjangan Kecil merupakan pulau yang terletak di sebelah barat daya Pulau Karimunjawa, memiliki pasir putih dan pemandangan bawah laut yang menakjubkan. Banyaknya jumlah wisatawan yang datang ke Pulau Menjangan Kecil memberikan dampak terhadap ekosistem terumbu karang sehingga mengancam keberlanjutan pariwisata dan perikanan di Karimunjawa. Berdasarkan studi pendahuluan yang telah dilakukan, umumnya degradasi terjadi pada kedalaman 2 meter yang disebabkan oleh aktivitas snorkeling yang tidak ramah lingkungan berupa patahan dan goresan akibat kibasan fins. Hal ini diperkuat oleh Biondi (2014), bahwa peningkatan jumlah kunjungan wisata di Taman Nasional Karimunjawa tersebut mengakibatkan penurunan tutupan terumbu karang. Oleh karena itu diperlukan infomasi mengenai parameter lingkungan dan laju pertumbuhan terumbu karang yang mendominasi perairan tersebut untuk upaya pengelolaan yang tepat. Tujuan dari penelitian ini adalah untuk mengetahui kondisi fisika kimia perairan di Pulau Menjangan Kecil, mengetahui kondisi tutupan dan jenis karang yang hidup di titik pengamatan di Pulau Menjangan Kecil, mengetahui laju pertumbuhan terumbu karang di Pulau Menjangan Kecil dan korelasi antara variabel fisika kimia perairan terhadap laju pertumbuhan terumbu karang.

\section{MATERI DAN METODE}

A. Waktu dan Tempat

Penelitian ini dilaksanakan pada bulan Februari - Juni 2018 di perairan Pulau Menjangan Kecil, Taman

Nasional Karimunjawa. Sampling dilakukan pada koordinat 5 53'14,968” LS 110²4’22,676 BT.

\section{B. Pengumpulan Data}

Metode dalam pengambilan data yaitu metode eksplanatif. Penelitian ini dilakukan selama 5 bulan dan

dibagi dalam 5 sesi. Sesi pertama yaitu studi pendahuluan. Sesi kedua dilakukan pemasangan kabel ties pada fragmen, pengukuran awal panjang fragmen karang (Lo) dan pengukuran fisika kimia perairan. Sesi ketiga dilakukan pengamatan pertumbuhan terumbu karang $\left(\mathrm{L}_{1}\right)$ dan kondisi fisika kimia perairan. Sesi keempat dilakukan pengamatan pertumbuhan terumbu karang $\left(\mathrm{L}_{2}\right)$ dan kondisi fisika kimia perairan. Sesi kelima dilakukan pengamatan tutupan terumbu karang pada kedalaman 2 m, pertumbuhan terumbu karang $\left(\mathrm{L}_{3}\right)$ dan kondisi fisika kimia perairan. Parameter fisika dan kimia yang diukur adalah suhu, salinitas dan kecerahan. Tutupan terumbu karang diukur menggunakan metode Line Intercept Transect.

\section{Analisis Data \\ 1. Tutupan terumbu karang}

Metode pengambilan data kondisi terumbu karang di Perairan Maer ditentukan melalui perhitungan presentase penutupan karang hidup, karang mati, karang mati dengan alga dan pasir. Kriteria kondisi terumbu karang ditentukan oleh nilai presentase penutupan karang hidup. Kriteria Baku Kerusakan Terumbu Karang dapat dilihat pada Tabel 1 .

Tabel 1. Kriteria Penilaian Kondisi TerumbuKarang Berdasarkan Presentase Penutupan Karang

Persentase penutupan karang $(\%)$

Kondisi terumbu karang

\begin{tabular}{cc}
\hline$<25$ & buruk \\
$25-50$ & sedang \\
$50-75$ & baik \\
$>75$ & sangat baik \\
\hline
\end{tabular}

Sumber. KepMen LH No.04 Tahun 2001

Persentase penutupan karang hidup ditentukan dengan rumus sebagai berikut English et. al. (1994) :

$$
\mathrm{L} \quad n i=\frac{l i}{L} \times 100 \%
$$

Keterangan : $\quad=$ Persentase penutupan karang hidup $(\%)$

$\mathrm{Ni} \quad=$ Panjang koloni karang hidup $(\mathrm{cm})$

li $\quad=$ Panjang transek garis $(\mathrm{cm})$ 
2. Pengukuran jenis karang yang dominan

Perhitungan jenis karang yang dominan ditentukan dengan rumus sebagai berikut (English et al., 1994) :

$$
\% \text { cover } \mathrm{X}=\frac{\text { total length of } \mathrm{X}}{\text { total length of the transect }} \times 100
$$

\section{Pengukuran laju pertumbuhan karang}

Pertambahan panjang karang dihitung dengan menggunakan rumus (Aziz,2002) :

$$
\boldsymbol{\beta}=\mathbf{L t}-\mathbf{L o}
$$

Keterangan:

$\beta=$ Pertambahan panjang fragmen karang $(\mathrm{mm})$

Lt $\quad=$ Panjang pada waktu ke-t $(\mathrm{mm})$

Lo $\quad=$ Panjang semula/awal $(\mathrm{mm})$

Sedangkan laju pertumbuhan karang dihitung dengan menggunakan rumus (Aziz, 2002) sebagai berikut :

$$
\alpha=\frac{L_{i+1}-L_{i}}{t_{i+1} \cdot t_{i}}
$$

Keterangan:

$$
\begin{aligned}
& \alpha \quad=\text { Laju pertumbuhan panjang fragmen karang }(\mathrm{mm} / \mathrm{hari}) \\
& \begin{array}{l}
\mathrm{L}++1=\text { Rata-rata panjang fragmen karang pada waktu ke-i+1 } \\
\mathrm{Lt} \quad=\text { Rata-rata panjang fragmen pada waktu } \mathrm{k}-\mathrm{i} \\
\mathrm{t}_{\mathrm{i}+1} \quad=\text { Waktu } \mathrm{k}-\mathrm{i}+1
\end{array}
\end{aligned}
$$

\section{HASIL DAN PEMBAHASAN}

A. HASIL

\section{Kondisi Fisika Kimia Perairan}

Kondisi fisika kimia perairan yang terdiri dari suhu, kecerahan perairan dan salinitas diukur secara insitu bersama dengan pengukuran pertambahan terumbu karang. Sedangkan pasang surut air laut dan kecepatan arus diperoleh melalui data Pushidros TNI AL. Hasil dari pengukuran kondisi fisika kimia perairan dapat dilihat pada Tabel 2.

Tabel 2. Hasil Pengukuran Fisika Kimia

\begin{tabular}{lccccc}
\hline & Suhu $\left({ }^{0} \mathrm{C}\right)$ & Kecerahan $(\mathrm{m})$ & Salinitas $(\% 0)$ & Pasut $(\mathrm{m})$ & Arus $(\mathrm{m} / \mathrm{s})$ \\
\hline Pengukuran I (0 hari) & 29 & $100 \%$ & 35 & 0,4 & 0,98 \\
Pengukuran II (30 hari) & 30 & $100 \%$ & 35 & 0,6 & 0,87 \\
Pengukuran III (60 hari) & 27 & $100 \%$ & 35 & 0,8 & 0,82 \\
Pengukuran IV (90 hari) & 28 & $100 \%$ & 35 & 0,9 & 0,36 \\
\hline Rata-rata & 28,5 & $100 \%$ & 35 & 0,68 & 0,76 \\
\hline
\end{tabular}

\section{Tutupan terumbu karang dan jenis karang hidup}

a. Tutupan terumbu karang

Hasil yang didapat dari pengamatan tutupan karang dengan metode line transek disajikan dalam Tabel 3 di bawah ini :

Tabel 3. Rata-rata Persentase Penutupan Karang

\begin{tabular}{clcc}
\hline \multirow{2}{*}{ No. Jenis Penutupan } & \multicolumn{2}{c}{ Kedalaman 2m } \\
\cline { 3 - 4 } & & $\mathrm{cm}$ & $\% 1,92$ \\
\cline { 3 - 4 } 2 & Karang hidup & 1857,5 & 15,67 \\
3 & Karang mati & 470 & 9,17 \\
4 & Pecahan karang & 275 & 13,25 \\
\hline & Pasir & 397,5 & 100 \\
\hline
\end{tabular}

b. Jenis karang hidup

Hasil dari pengamatan terhadap kondisi terumbu karang, didapatkan ada beberapa jenis karang yang hidup di lingkungan tersebut. Jenis karang yang ditemukan disajikan pada Tabel 4. 
Tabel 4. Jenis Karang yang Ditemukan dan Prosentasenya

\begin{tabular}{|c|c|c|c|c|c|c|}
\hline \multirow{2}{*}{ No. } & \multirow{2}{*}{ Genus/Jenis Karang } & \multicolumn{2}{|c|}{ Kedalaman $2 \mathrm{~m}$} & \multirow{2}{*}{$\overline{\mathrm{x}}$} & \multirow{2}{*}{$\mathrm{Pi}$} & \multirow{2}{*}{$\%$} \\
\hline & & I & II & & & \\
\hline 1 & Montipora & 0 & 120 & 60 & 0,03 & 3,23 \\
\hline 2 & Porites Cylindrica & 100 & 84 & 92 & 0,05 & 4,95 \\
\hline 3 & Fungia sp. & 30 & 0 & 15 & 0,01 & 0,81 \\
\hline 4 & Goniastrea sp. & 50 & 30 & 40 & 0,02 & 2,15 \\
\hline 5 & Turbinaria sp. & 90 & 40 & 65 & 0,04 & 3,50 \\
\hline 6 & Hydnophora rigida & 35 & 15 & 25 & 0,01 & 1,35 \\
\hline 7 & Acropora divaricata & 670 & 250 & 460 & 0,25 & 24,77 \\
\hline 8 & Acropora digitifera & 360 & 240 & 300 & 0,16 & 16,16 \\
\hline 9 & Acropora formosa & 1020 & 500 & 760 & 0,41 & 40,93 \\
\hline 10 & Favia & 20 & 60 & 40 & 0,02 & 2,15 \\
\hline & JUMLAH & 2375 & 1339 & 1857 & 1 & 100 \\
\hline
\end{tabular}

Berdasarkan Tabel 4 jenis karang hidup di Pulau Menjangan Kecil diantaranya dari genus Acropora, Porites, Turbinaria, Montipora dan beberapa jenis lainnya. Berdasarkan hasil pengamatan karang yang paling sering ditemui adalah Acropora formosa (40,93\%) dan Acropora divaricata (24,77\%). Ciri - ciri jenis karang dominan yang ditemukan di Pulau Menjangan Kecil, Karimunjawa disajikan dalam Tabel 5. Tabel 5. Jenis Karang yang Dominan dan Ciri-Cirinya

\begin{tabular}{|c|c|c|c|}
\hline $\mathrm{No}$ & Jenis Karang & Gambar & Ciri-ciri \\
\hline 1. & Acropora formosa & & $\begin{array}{l}\text { 1. Bentuk percabangan } \\
\text { ramping sampai gemuk } \\
\text { 2. Koralit tersusun merata } \\
\text { dan rapat } \\
\text { 3. Berwarna coklat muda, } \\
\text { coklat tua dan kadang- } \\
\text { kadang biru } \\
\text { (Suharsono, 2008) }\end{array}$ \\
\hline 2. & $\begin{array}{l}\text { Acropora } \\
\text { divaricata }\end{array}$ & & $\begin{array}{l}\text { 1. Bentuk percabangan } \\
\text { yang bervariasi } \\
\text { 2. Axial koralit berbentuk } \\
\text { tabung, radial koralit } \\
\text { berjajar } \\
\text { 3. Berwarna coklat muda } \\
\text { (Suharsono, 2008) }\end{array}$ \\
\hline
\end{tabular}

\section{Analisis Laju Pertumbuhan Terumbu Karang}

a. Waktu pengukuran terhadap laju pertumbuhan terumbu karang

Berdasarkan data yang diperoleh, rata-rata penambahan panjang fragmen pada bulan Maret-April adalah 5,22 $\mathrm{mm}$, pada bulan April-Mei adalah 5,39 $\mathrm{mm}$ dan pada bulan Mei-Juni adalah sebesar 5,78 mm. Laju pertumbuhan terumbu karang mengalami kenaikan selama 3 kali pengamatan. Grafik rata-rata laju pertumbuhan terumbu karang berdasarkan waktu pengambilan data dapat dilihat dapat dilihat pada Gambar 1.

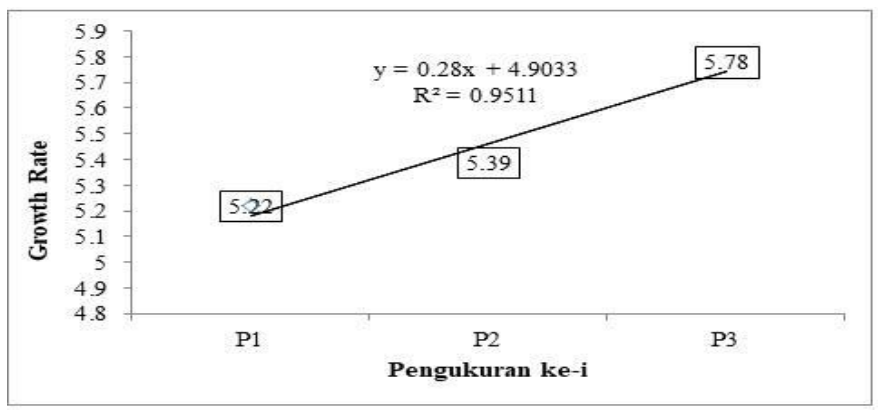

Gambar 1. Grafik Rata-Rata Laju Pertumbuhan Karang

Berdasarkan Gambar 1 nilai $\mathrm{R}^{2}=0,9511$ atau 95,1\%. Angka tersebut mengandung arti bahwa waktu pengukuran berpengaruh terhadap laju pertumbuhan terumbu karang sebesar $95,1 \%$, sedangkan sisanya $4,9 \%$ dipengaruhi oleh variabel lain. Nilai r sebesar 0,9752 menunjukkan hubungan antara waktu pengukuran dengan laju pertumbuhan terumbu karang sangat kuat. 


\section{b. Analisis hubungan antara variabel fisika kimia perairan dengan laju pertumbuhan karang}

Berdasarkan uji normalitas menggunakan Shapiro-Wilk, hasil menunjukkan nilai data berdistribusi normal, sehingga digunakan uji Pearson untuk melihat variabel manakah yang memiliki korelasi paling besar terhadap laju pertumbuhan karang. UJi Pearson menggunakan taraf kepercayaan 95\% (Sarwono, 2006). Hasil Uji Korelasi Pearson disajikan dalam Tabel 6 sebagai berikut :

Tabel 6. Analisis Uji Pearson antara Variabel Fisika Kimia Perairan dengan Laju Pertumbuhan Karang

\begin{tabular}{|c|c|c|c|c|c|c|}
\hline & Temperatur & Kecerahan & & & Arus & Pasut \\
\hline Pearson Correlation & $-0,344$ & & - & - & $-0,724$ & 0,675 \\
\hline Sig. (2-tailed) & 0,364 & & - & - & 0,027 & 0,046 \\
\hline $\mathrm{N}$ & 9 & & 9 & 9 & 9 & 9 \\
\hline
\end{tabular}

Berdasarkan hasil analisis dapat diketahui bahwa, variabel fisika kimia perairan yang memiliki hubungan terhadap laju pertumbuhan terumbu karang adalah arus dan pasang surut air laut dengan nilai Sig. 0,027<0,05 dan Sig. 0,046<0,05. Temperatur air laut tidak memiliki korelasi terhadap laju pertumbuhan terumbu karang dengan nilai Sig. 0,364>0,05. Sedangkan kecerahan dan salinitas memiliki nilai nol.

\section{B. PEMBAHASAN}

\section{Kondisi Fisika Kimia Perairan}

Pengukuran parameter lingkungan perairan dilakukan untuk mengetahui kondisi perairan di titik pengamatan. Pertumbuhan dan perkembangan terumbu karang sangat dipengaruhi oleh kualitas perairan. Hasil dari pengukuran salinitas menggunakan refraktometer selama kali pengukuran nilai salinitasnya sama, yaitu sebesar $35 \%$. Nilai salinitas tersebut masih dalam kisaran normal untuk pertumbuhan terumbu karang. Hal ini diperkuat oleh Pangaribuan et al., (2013), bahwa salinitas 25-40\% masih baik untuk pertumbuhan dan perkembangan karang, hal ini dikarenakan perairan berhubungan secara bebas dengan ditunjang arus yang cukup sehingga menunjang salinitasnya. Salinitas air laut tropis kurang lebih berkisar $35^{\circ} \%$.

Hasil pengukuran tingkat kecerahan perairan pada kedalaman $2 \mathrm{~m}$ memiliki nilai kecerahan sampai $2 \mathrm{~m}$, hal tersebut menunjukkan bahwa cahaya matahari mencapai dasar perairan dan baik untuk ekosistem terumbu karang. Menurut KepMenLH No.51 (2004), kecerahan air suatu perairan merupakan faktor yang penting baik untuk kehidupan biota dalam kolom air laut maupun untuk objek wisata di laut. Nilai kecerahan yang sesuai dengan kriteria yang ditetapkan yakni $>5$ meter untuk terumbu karang.

Pada pengukuran temperature air, terdapat perbedaan nilai temperatur yakni pengamatan awal memiliki nilai sebesar $29^{\circ} \mathrm{C}$, pengamatan kedua mimiliki nilai sebesar $30^{\circ} \mathrm{C}$, sedangkan pengamatan ketiga sebesar $27^{\circ} \mathrm{C}$ dan pengamatan keempat sebesar $28^{\circ} \mathrm{C}$. Hal ini menunjukkan bahwa nilai yang diperoleh cukup stabil dengan fluktuasi sebesar $3^{0} \mathrm{C}$ dan suhu tersebut tergolong kategori normal. Supriharyono (2007) mengatakan bahwa Acropora dapat hidup di perairan dengan kisaran suhu $16-40^{\circ} \mathrm{C}$, dan karang Porites merupakan koloni karang yang paling tahan terhadap suhu yang ekstrem. Hal tersebut diperkuat oleh Souhoka dan Patty (2013), bahwa kisaran suhu yang teramati masih dalam batas kisaran optimal suhu air laut yaitu $28-32^{0} \mathrm{C}$. Secara umum suhu tersebut baik untuk kehidupan dan reproduksi terumbu karang.

\section{Tutupan Terumbu Karang}

Berdasarkan hasil pengamatan yang dilakukan pada saat penelitian lapangan pada kedalaman 2 meter Pulau Menjangan Kecil rata - rata tutupan terumbu karangnya bernilai 61,92\%. Menurut KepMen LH No. 4 Tahun 2001 kondisi lingkungan yang memiliki tutupan karang hidup yang lebih dari $50 \%$ masih dalam kategori baik meskipun dinilai telah terjadi degradasi. Menurut Statistik Balai Taman Nasional Karimunjawa Tahun 2016 secara umum presentase tutupan terumbu karang di kawasan Taman Nasional Karimunjawa berada pada rerata 49,89\% dan termasuk kategori baik. Meskipun demikian, langkah preventif perlu dilakukan untuk menjaga kelestarian ekosistem terumbu karang terlebih Pulau Menjangan Kecil merupakan zona pemanfaatan wisata bahari.

Karang dominan yang ditemukan saat pengamatan adalah Acropora divaricata dan Acropora formosa. Kondisi perairan yang tenang merupakan habitat yang cocok untuk karang dengan tipe pertumbuhan bercabang. Selain kedua karang tersebut ditemukan pula beberapa jenis karang seperti Porites, Turbinaria, Montipora, dan lain - lain. Karang - karang tersebut ditemukan tumbuh mengelilingi Pulau Menjangan Kecil. Menurut Pardede et al. (2016) tipe habitat terumbu karang di Karimunjawa adalah karang tepi. Faktor fisika perairan seperti arus dan intensitas gelombang yang tidak terlalu besar mempengaruhi jenis karang keras yang ada perairan tersebut, sehingga perairannya didominasi oleh karang dari genus Porites dan Acropora.

\section{Laju pertumbuhan terumbu karang}

Laju pertumbuhan karang Acropora formosa merupakan selisih perubahan tinggi karang pada setiap pengamatan. Pengamatan dilakukan setiap 30 hari atau setiap bulan selama 4 bulan sehingga diperoleh 3 nilai ratarata pertumbuhan fragmen karang. Berdasarkan analisis tutupan terumbu karang, diperoleh hasil bahwa jenis karang yang mendominasi adalah Acropora formosa. Karang Acropora formosa merupakan terumbu karang dengan bentuk pertumbuhan branching. Sehingga jenis karang tersebut digunakan untuk sampel pengukuran laju pertumbuhan karang. Fragmen karang diletakkan pada kedalaman $2 \mathrm{~m}$. Hal ini dikarenakan untuk memudahkan peneliti dalam mengamati dan mengukur pertumbuhan karang tersebut. Menurut Agustina et al., (2016), bahwa karang jenis Acropora formosa banyak dijumpai hidup pada kedalaman 3-15 meter. Ciri-ciri dari karang tersebut adalah koloni 
bercabang, ujung cabangnya lancip dan mempunyai warna biru muda atau coklat. Klasifikasi jenis karang Acropora formosa adalah sebagai berikut :

$\begin{array}{ll}\text { Kingdom } & \text { : Animalia } \\ \text { Phylum } & \text { : Cnidaria } \\ \text { Class } & \text { : Anthozoa } \\ \text { Ordo } & \text { : Scleractinia } \\ \text { Family } & \text { : Acroporidae } \\ \text { Genus } & \text { : Acropora } \\ \text { Species } & \text { : Acropora formosa }\end{array}$

Nilai rata-rata laju pertumbuhan karang yang diperoleh adalah 5,47 mm/bln. Laju pertumbuhan karang tersebut masih dalam kategori normal dan cenderung tinggi hal ini dikarenakan oleh kondisi ekologi di area tersebut sesuai untuk pertumbuhan karang Acropora formosa. Hal ini diperkuat oleh Suharso (2008), bahwa area terumbu karang yang telah rusak pada dasarnya memiliki kemampuan untuk pulih secara alami tetapi membutuhkan waktu yang lama. Beberapa penelitian mengungkapkan karang memiliki pertumbuhan yang cukup lambat. Jenis-jenis karang bercabang seperti Acropora dan Pocillopora memiliki pertumbuhan 6-8 cm/tahun sedang jenis karang massive seperti Porites dan Lobophyllia memiliki pertumbuhan 0,5-1 cm/tahun.

Laju pertumbuhan terumbu krang yang telah diamati memliki rata-rata yang berbeda antar koloni. Koloni 1 memiliki rata-rata 5,53 mm/bulan, koloni 2 memiliki rata-rata 5,56 mm/bulan, sedangkan koloni 3 memiliki rata-rata sebesar 5,38 mm/bulan. Hal ini menunjukkan bahwa karang dalam satu koloni maupun dalam koloni yang berbeda memiliki laju pertumbuhan yang tidak sama meskipun karang-karang tersebut tumbuh dalam tahun yang sama, kedalaman yang sama dan pada lokasi yang sama. Hal ini diperkuat oleh Nugraha (2008), bahwa terumbu karang dalam satu koloni memiliki laju pertumbuhan rata-rata karang yang tidak sama meskipun tumbuh dalam waktu yang sama. Selain itu laju pertumbuhan karang antara satu koloni dengan koloni yang lain juga berbeda meskipun memiliki persamaan lokasi dan kedalaman yang sama.

\section{Waktu pengukuran terhadap laju pertumbuhan terumbu karang}

Pengukuran laju pertumbuhan terumbu karang memiliki rentang waktu 30 hari setiap kali pengukuran dengan pengukuran selanjutnya. Berdasarkan nilai $\mathrm{R}^{2}$ dan $\mathrm{r}$ menunjukkan bahwa waktu pengukuran memiliki hubungan dan berpengaruh terhadap laju pertumbuhan karang. Waktu pengukuran secara tidak langsung mempengaruhi laju pertumbuhan karang dikarenakan adanya variasi kondisi lingkungan perairan yang berubah-ubah sehingga secara langsung berdampak pada pertumbuhan karang. Kondisi lingkungan yang sangat mempengaruhi pertumbuhan karang adalah densitas cahaya, dimana densitas cahaya mempengaruhi kecepatan fotosintesis pada terumbu karang. Hal ini diperkuat oleh Dahuri (2003), bahwa ekosistem terumbu karang merupakan ekosistem yang sangat rentan terhadap gangguan perubahan lingkungan laut. Hal ini juga diperkuat oleh Luthfi et al. (2016), bahwa pada saat musim hujan, cahaya yang masuk kurang atau sedikit sehingga pertumbuhan karang jadi terhambat, sedangkan pada musim kemarau cahaya yang masuk kedalam perairan cukup kuat sehingga terumbu karang memiliki pertumbuhan karang yang lebih cepat.

\section{Korelasi antara variabel fisika kimia perairan dengan laju pertumbuhan karang}

Berdasarkan hasil pengukuran parameter fisika kimia perairan secara in situ, dapat dilihat bahwa nilai salinitas dan kecerahan selama pengamatan memiliki nilai yang sama. Namun, hasil pengukuran temperatur air laut memiliki perbedaan nilai selama penelitian. Berdasarkan hasil pengukuran laju pertumbuhan karang selama 3 bulan diperoleh nilai bahwa rata-rata pertumbuhan karang pada tiap-tiap koloni berbeda. Meskipun perbedaan nilai ratarata laju pertumbuhan terumbu karang tersebut memiliki selisih yang kecil.

Berdasarkan uji normalitas menggunakan Shapiro Wilk, sebaran data pada laju pertumbuhan karang berdistribusi normal. Oleh karena itu dilakukan uji lanjutan untuk mengetahui adakah korelasi antara variabel fisika kimia perairan terhadap laju pertumbuhan terumbu karang. Analisis hubungan variabel fisika kimia perairan terhadap laju pertumbuhan terumbu karang dilakukan secara parametrik menggunakan Uji Pearson. Berdasarkan uji korelasi Pearson dengan tingkat ketelitian $95 \%$ pada hubungan antara variabel fisika kimia perairan dengan laju pertumbuhan karang Acropora formosa diperoleh nilai signifikansi sebesar 0,364 pada temperatur. Oleh karena itu dapat disimpulkan bahwa temperatur tidak memiliki hubungan terhadap laju pertumbuhan terumbu karang. Sedangkan arus memiliki nilai Sig. 0,027 dan pasut memiliki nilai Sig. 0,046 dimana nilai tersebut kurang dari 0,5 atau dapat disimpulkan bahwa arus dan pasang surut air laut memiliki hubungan terhadap laju pertumbuhan terumbu karang. Sedangkan parameter lain, seperti salinitas dan kecerahan memiliki nilai nol. Hal tersebut diduga disebabkan karena nilai yang konstan dalam beberapa kali pengukuran. Berdasarkan hasil tersebut, maka terima H0 dan tolak H1 untuk variabel temperatur dapat dikatakan bahwa tidak ada hubungan antara temperatur air laut pada saat penelitian dengan laju pertumbuhan terumbu karang. Sedangkan untuk variabel arus dan pasut maka kesimpulan yang dapat diambil adalah terima $\mathrm{H} 1$ dan tolak $\mathrm{H} 0$ dan dapat dikatakan bahwa pasut dan arus memiliki hubungan terhadap laju pertumbuhan terumbu karang.

Berdasarkan analisis data temperatur air laut dikatakan tidak ada hubungan dengan laju pertumbuhan karang dikarenakan temperatur air laut bukan satu-satunya parameter yang mempengaruhi laju pertumbuhan karang. Hal ini diperkuat oleh Souhoka dan Patty (2013), bahwa pengamatan kualitas perairan merupakan salah satu faktor yang sangat penting terhadap kehidupan terumbu karang. Kualitas perairan yang cocok merupakan salah satu fasilitas yang memungkinkan terumbu karang dapat hidup, tumbuh dan berkembang dengan baik. Parameter lingkungan 
yang dapat mempengaruhi laju pertumbuhan karang selain suhu air laut adalah kecepatan arus,salinitas, kecerahan, fosfat, nitrat, $\mathrm{pH}$, pasang surut dan oksigen terlarut.

Variabel fisika berupa arus dan pasang surut air laut memiliki hubungan terhadap laju pertumbuhan karang. Hal ini dikarenakan biota karang mendapat suplai makanan dari air laut yang terbawa arus. Selain itu juga dapat mencegah endapan material menempel pada polip karang. Hal ini diperkuat oleh Giyanto et al., (2017), bahwa arus dan sirkulasi air diperlukan dalam penyuplaian makanan yang diperlukan dalam proses pertumbuhan terumbu karang dan suplai oksigen dari laut lepas. Selain itu, arus dan sirkulasi air juga berperan dalam proses pembersihan dari endapan meterial yang menempel pada polip karang. Tempat dengan arus dan ombak yang besar dapat mengganggu pertummbuhan karang misalnya pada daerah-dearah terbuka yang langsung menghadap ke laut lepas dengan ombak yang besar sepanjang masa.

\section{KESIMPULAN}

Kesimpulan yang dapat diambil dari penelitian ini yaitu : kondisi fisika kimia perairan secara in situ di titik pengamatan selama pengukuran pertumbuhan terumbu karang tergolong baik yaitu sekitar $27-30^{0} \mathrm{C}$ dengan fluktuasi sebesar $3^{0} \mathrm{C}$, kecerahan hingga dasar perairan dan salinitas sebesar $35 \mathrm{ppm}$. Kondisi perairan tersebut dapat mendukung keberlanjutan ekosistem terumbu karang, tutupan karang di titik pengamatan tergolong baik dengan persentase penutupan sebesar $61,92 \%$ dan jenis karang yang dominan di titik pengamatan tersebut adalah jenis Acropora formosa dan Acropora divaricate. Nilai rata-rata laju pertumbuhan karang yang diperoleh sebesar 5,47 $\mathrm{mm} / \mathrm{bln}$. Perbedaan waktu pengambilan data memberikan pengaruh terhadap laju pertumbuhan karang. Hasil Uji Pearson menunjukkan bahwa temperature tidak memiliki hubungan terhadap laju pertumbuhan terumbu karang, arus dan pasut memiliki hubungan terhadap laju pertumbuhan terumbu karang, sedangkan parameter lain seperti salinitas dan kecerahan memiliki nilai nol.

\section{UCAPAN TERIMA KASIH}

Penulis mengucapkan terima kasih kepada Allah SWT yang telah memberikan rahmat dan karunia-Nya sehingga penulis dapat menyelesaikan penelitian ini. Terima kasih kepada Bapak Dr. Ir. Sulardiono, M.Si. dan Ibu Niniek Widyorini, MS. yang telah memberi masukan untuk penelitian ini, kepada pihak Balai Taman Nasional Karimunjawa yang telah memberikan izin dan segala informasi dalam penelitian ini. Serta kepada seluruh pihak yang membantu selama penelitian ini dan memberikan semangat untuk terselesainya penelitian ini.

\section{DAFTAR PUSTAKA}

Agustina, E., M. A. Mardiansyah, M. Doudi dan S. Annas. 2016. Karakteristik Spesies Karang di Perairan Rinon Pulo Breueh. Prosiding Seminar Nasional Biotik. 43-48

Aziz, A.M. 2002. Tingkat Kelangsungan Hidup, Laju Pertumbuhan dan Rasio Pertumbuhan Beberapa Jenis Karang Batu dan Karang Api yang Ditransplantasikan di Perairan Pulau Pari. Ilmu dan Teknologi Kelautan. IPB. Bogor, $15 \mathrm{hlm}$

Biondi, I., Munasik dan Koesoemadji. 2014. Kondisi Terumbu Karang pada Lokasi Wisata Snorkeling di Kepulauan Karimunjawa, Jawa Tengah. Jurnal of Marine Research. 3(3) : 182-201

Dahuri, R. 2003. Keanekaragaman Hayati Laut, Aset Pembangunan Berkelanjutan Indonesia, Gramedia Pustaka, Jakarta.

English, S., C. Wilkinson and V. Baker. 1994. Survey Manual for Tropical Marine Resources. $2^{\text {nd }}$ Edition. Australian Institute of Marine Science. 383 pages

Giyanto, M. Abrar, T. A. Hadi, A. Budiyanto, M. Hafizt, A. Salatalohy, M. Y. Iswari. 2017. Status Terumbu Karang Indonesia 2017. COREMAP-CTI Pusat Penelitian Oseanografi, Jakarta, $30 \mathrm{hlm}$.

Keputusan Menteri Negara Lingkungan Hidup No.51 Tahun 2004 tentang Baku Mutu Air Laut untuk Biota Laut. Jakarta

Keputusan Menteri Negara Lingkungan Hidup No.04 Tahun 2001 Tentang Kriteria Baku Kerusakan Terumbu Karang

Luthfi, O. M., D. Varaghi, S. R. Fakri. A.Jauhari, Guntur dan Sunardi. 2016. Seminar Nasional Perikanan dan Kelautan VI. Fakultas Perikanan dan Ilmu Kelautan, Universitas Brawijaya Malang. 550-555

Nugraha, W.A. 2008. Laju Pertumbuhan Karang Porites lutea Di Karimunjawa dan Bangkalan, Indonesia. Jurnal Embryo. 5(1):24-33

Pardede, S., S.A.R. Tarigan, F. Setiawan, E. Muttaqin, A. Muttaqin dan Muhidin. 2016. Laporan Teknis : Monitoring Ekosistem Terumbu Karang Taman Nasional Karimunjawa 2016. Wildlife Conservation Society Bogor. Indonesia. $68 \mathrm{hlm}$ 
Pangaribuan, T.H., C. Ain dan P. Soedarsono. 2013. Hubungan Kandungan Nitrat dan Fosfat dengan Densitas Zooxanthellae Pada Polip Karang Acropora sp. Di Perairan Terumbu Karang Pulau Menjangan Kecil, Karimunjawa. Jurnal of Maquares, 2(4):136-145

Salim, D. 2012. Pengelolaan Ekosistem Terumbu Karang Akibat Pemutihan (Bleaching) dan Rusak. Jurnal Kelautan, 5(2):142-155.

Sarwono, Jonathan. 2006. Analisis Data Penlitian Menggunakan SPSS. Andi Offset. Yogyakarta. 503 hlm

Souhoka, J. dan S.I. Patty. 2013. Pemantauan Kondisi Hidrologi dalam Kaitannya dengan Kondisi Terumbu Karang di Perairan Pulau Talise, Sulawesi Utara. Jurnal Ilmiah Platax, 1(3):138-147

Suharsono. 2008. Jenis-jenis Karang di Indonesia. Program COREMAP LIPI. LIPI Press, Jakarta, 344 hlm

Supriharyono. 2007. Pengelolaan Ekosistem Terumbu Karang . Ed.2, Djambatan, Jakarta, 129 hlm. 